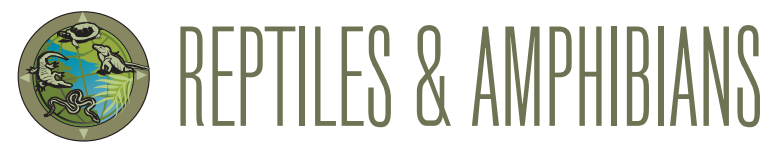

\title{
Notes on Two Species of Threatened Turtles at the Forestry Campus Complex, Hetauda, Malkwanpur, Nepal
}

\author{
Sandeep Chhetri Luitel ${ }^{1}$, Aavas Pradhan ${ }^{2,3}$, Bhuwan Singh Bist ${ }^{2,3}$, Arjun Bhusal2,4 and Rakshanda Sedhain ${ }^{5}$ \\ ${ }^{1}$ Agriculture and Forestry University, Faculty of Forestry, Hetauda, Makwanpur \\ ${ }^{2}$ School of Forestry and Natural Resources Management, Institute of Forestry, Tribhuvan University, Kirtipur, Nepal \\ ${ }^{3}$ Teka Samuha Nepal, Kathmandu, Nepal (pradhan.aavas004@gmail.com; aavas.763505@sofnrm.tu.edu.np) \\ ${ }^{4}$ Green Governance Nepal, Kathamandu, Nepal \\ ${ }^{5}$ Division Forest Office, Ministry of Industry, Tourism, Forest and Environment, Birendranagar, Surkheat, Karnali Pardesh, Nepal
}

$\mathrm{F}^{\mathrm{n}}$ rom 7 April to 5 July 2019, we observed six Elongated Tortoises, Indotestudo elongata (Blyth 1854) (Fig. 1), and four Tricarinate Hill Turtles, Melanochelys tricarinata (Blyth 1856) (Fig. 2), during Visual Encounter Surveys (VES) (Foster et al. 2012; Hofmeyr and Henen 2016) along existing trails of the Forestry Campus Complex (FCC), Hetauda, Makwanpur, Nepal (Fig. 3). We also searched diligently for these species in various microhabitats around the periphery of the study site ( -97 ha) (Pradhan et al. 2020). Turtles were identified using field guides by Shah and Tiwari (2004) and Kästle et al. (2013). Both species are threatened with extinction; Indotestudo elongata is listed as Critically Endangered (CR) (Rahman et al. 2019) and Melanochelys tricarinata as Endangered (EN) (Horne et al. 2020) on the IUCN Red List of Threatened Species.

Of the six Elongated Tortoises, three were in closed-canopy forest (two in Rhino Apple [Trewia nudifora] and one in Sal [Shorea robusta] dominated forest), two in grassland, and one
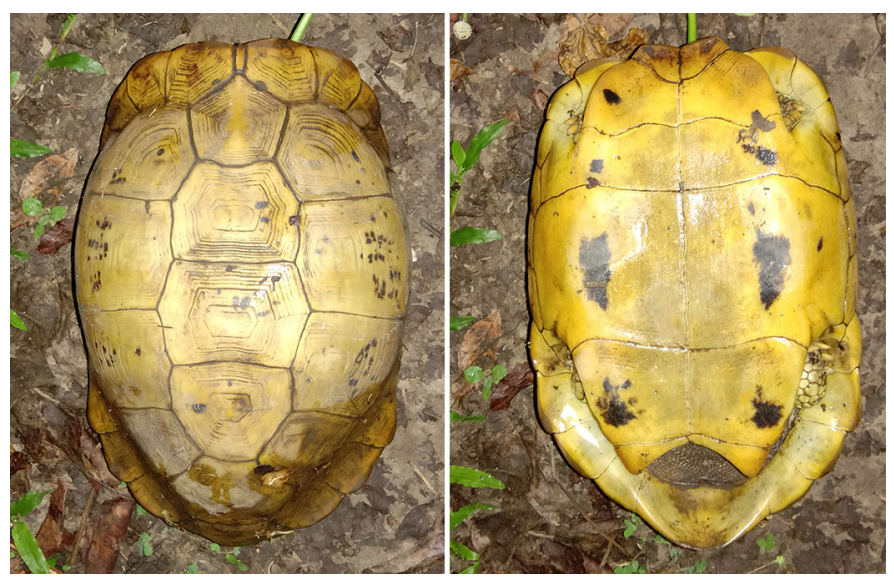

Fig. 1. Carapace (left) and plastron (right) of an Elongated Tortoise (Indotestudo elongata) at the Forestry Campus Complex, Hetauda, Makwanpur, Nepal. Photographs by Sandeep Chhetri Luitel. along the forest-settlement edge. Distance to water was 3-135 $\mathrm{m}($ mean $=40.3 \mathrm{~m})$ and distance to the settlement was 21-421 $\mathrm{m}(\mathrm{mean}=284.0 \mathrm{~m})$. Of the four Tricarinate Hill Turtles, two were in closed-canopy forest (one each in Rhino Apple and Sal dominated forest) and two were along the forest-settlement edge. Distance to water was $108-650 \mathrm{~m}($ mean $=355.0 \mathrm{~m})$ and distance to the settlement was $20-408 \mathrm{~m}($ mean $=236.9 \mathrm{~m})$.

During this study, we adventitiously encountered local residents hunting turtles for meat or as pets or even ornaments (Fig. 4). We also identified cattle grazing and human alteration of habitats, factors previously identified by Schleich and Kästle (2002), Leuteritz et al. (2005), and Moore and Seigel (2006) as threats to turtles, affecting the populations in the area. The current situation indicates an urgent need for educating the local community and for strong legal sanctions to conserve the local breeding populations of these two endangered species.

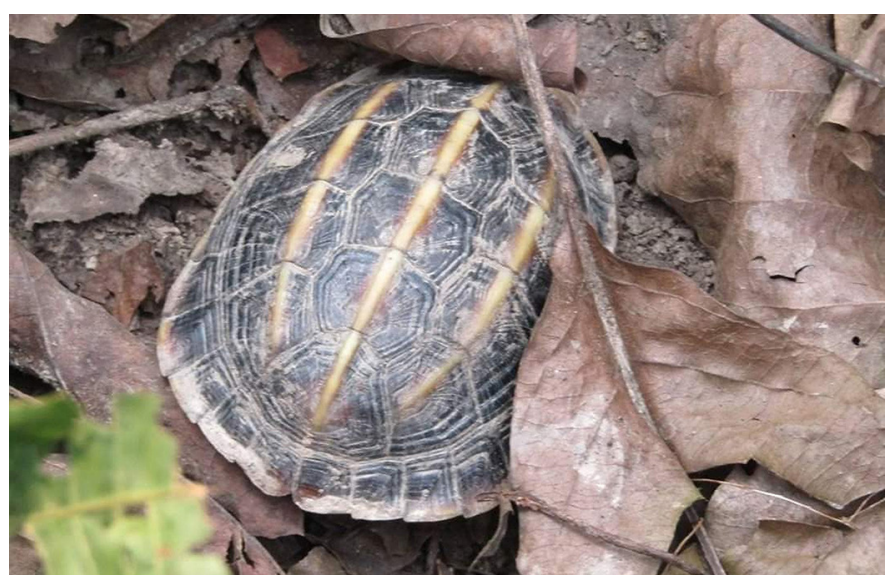

Fig. 2. A Tricarinate Hill Turtle (Melanochelys tricarinata) encountered at the Forestry Campus Complex, Hetauda, Makwanpur, Nepal. Photograph by Nahakul Bhusal. 


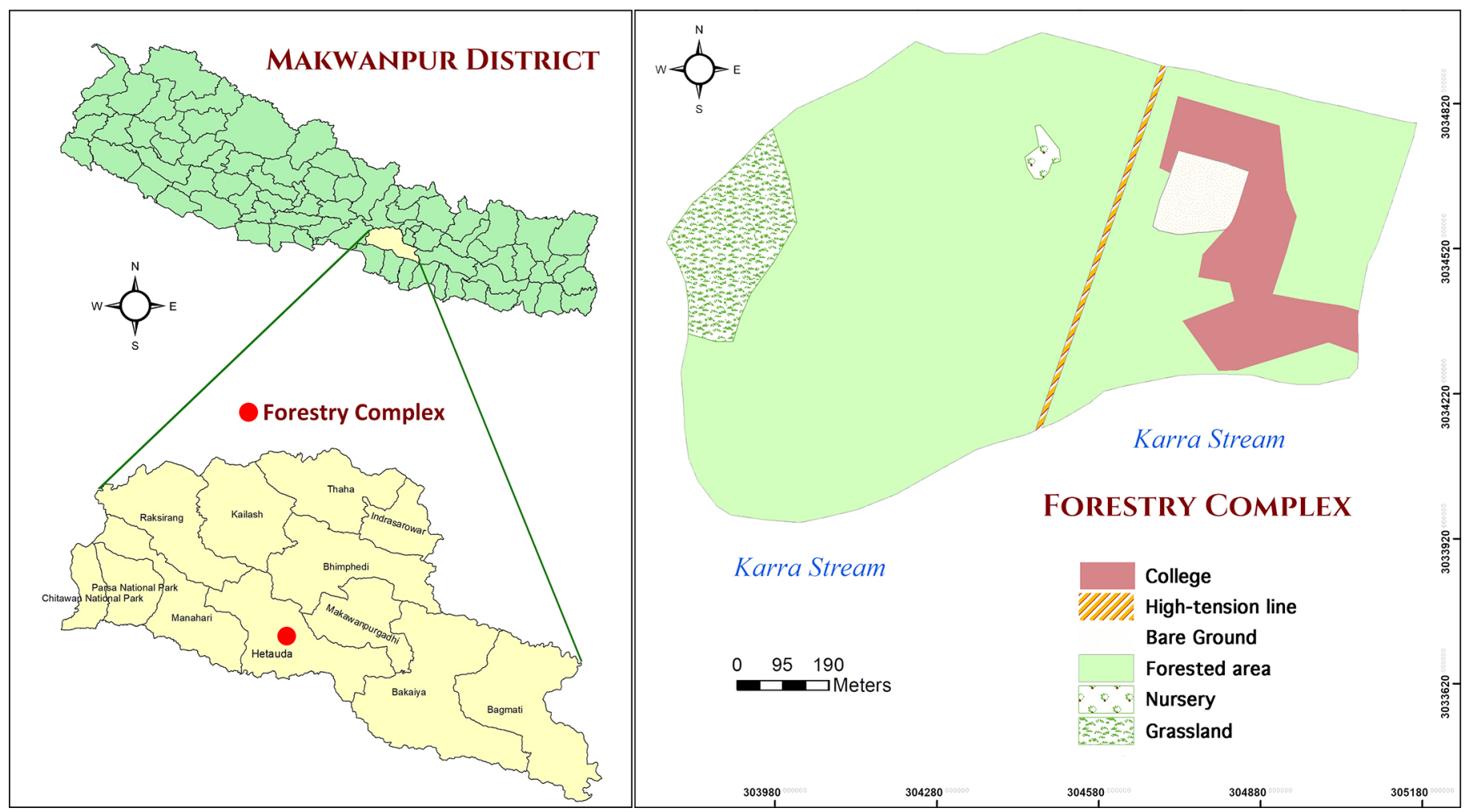

Fig. 3. Map of the Forestry Campus Complex, Hetauda, Makwanpur, Nepal.

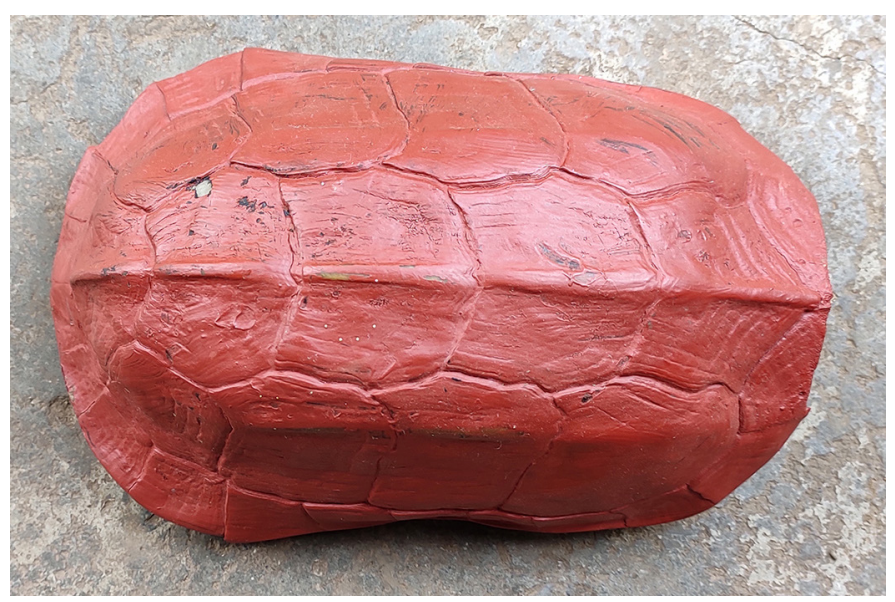

Fig. 4. Shell of a Tricarinate Hill Turtle (Melanochelys tricarinata) used for decorative purposes. Photograph by Sandeep Chhetri Luitel.

\section{Acknowledgements}

We express our deepest appreciation for suggestions and motivation to Menuka Maharjan, Ph.D. (Assistant Professor, Institute of Forestry, Hetauda), Mr. Tapil Rai (Coordinator, Turtle Rescue and Conservation Center, Jhapa), and Mr. Santosh Bhattarai (Conservation Officer, National Trust for Nature Conservation, Biodiversity Conservation Centre, Sauraha, Chitwan, Nepal). We extend our special thanks to Mr. Samit Kafle, Mr. Kapil Bastola, and Mr. Anish Dhakal for help during the field surveys, and to the faculty and staff of the Institute of Forestry, Hetauda Campus, Hetauda, and the Agriculture and Forestry University, Faculty of Forestry, Hetauda, who helped coordinate this study.

\section{Literature Cited}

Foster, M.S. 2012. Standard techniques for inventory and monitoring, pp. 205271. In: RW. McDiarmid, M.S. Foster, C. Guyer, N. Chernoff, and J.W. Gibbons (eds.), Reptile Biodiversity: Standard Methods for Inventory and Monitoring. University of California Press, Berkeley, California, USA.

Hofmeyr, M.D. and B.T. Henen. 2016. Terrestrial turtles and tortoises, pp. 181193. In: C.K. Dodd (ed.) Reptile Ecology and Conservation: A Handbook of Techniques. University of California Press, Berkeley, California, USA.

Horne, B.D., P. Praschag, B.C. Choudhury, and S. Singh. 2020. Melanochelys tricarinata. The IUCN Red List of Threatened Species 2020: e.T13038A511526. https://dx.doi.org/10.2305/IUCN.UK.2020-2.RLTS.T13038A511526.en.

Kästle, W., K. Rai, and H.H. Schleich. 2013. Field Guide to Amphibians and Reptiles of Nepal. ARCO-Nepal, München, Germany.

Leuteritz, T.E., T. Lamb, and J.C. Limberaza. 2005. Distribution, status, and conservation of radiated tortoises (Geochelone radiata) in Madagascar. Biological Conservation 124: 451-461. https://doi.org/10.1016/j.biocon.2005.02.003.

Moore, M.J. and R.A. Seigel. 2006. No place to nest or bask: Effects of human disturbance on the nesting and basking habits of yellow-blotched map turtles (Graptemys flavimaculata). Biological Conservation 130: 386-393. https://doi. org/10.1016/j.biocon.2006.01.001.

Pradhan, A., S. Bajagain, and R., Sedhain. 2020. Checklist of serpents in Institute of Forestry, Hetauda Campus Complex, Makwanpur, Nepal. The Himalayan Naturalist 3(1): 16-19.

Rahman, S., K. Platt, I. Das, B.C. Choudhury, M.F. Ahmed, M. Cota, T. McCormack, R.J. Timmins, and S. Singh. 2019. Indotestudo elongata (errata version published in 2019). The IUCN Red List of Threatened Species 2019: e.T10824A152051190. https://dx.doi.org/10.2305/IUCN.UK.2019-1. RLTS.T10824A152051190.en.

Schleich, H.H. and W. Kästle. 2002. Amphibians and Reptiles of Nepal. Biology, Systematics, Field Guide. A.R.G. Gantner Verlag, Ruggell, Liechtenstein.

Shah, K.B. and S. Tiwari. 2004. Herpetofauna of Nepal: A Conservation Companion. IUCN Nepal, Kathamandu, Nepal. 